\title{
Photosynthetic performance and anatomical adaptations in Byrsonima sericea DC. under contrasting light conditions in a remnant of the Atlantic forest.
}

\author{
Anandra S. Silva', Jurandi G. Oliveira², Maura da Cunha ${ }^{3}$, Angela P. Vitória ${ }^{1, *}$ \\ ${ }^{1}$ Laboratório de Ciências Ambientais, Centro de Biociências e Biotecnologia, Universidade Estadual do Norte \\ Fluminense Darcy Ribeiro. \\ ${ }^{2}$ Laboratório de Melhoramento Genético Vegetal, Centro de Ciências e Tecnologias Agropecuárias, Universidade \\ Estadual do Norte Fluminense Darcy Ribeiro. \\ ${ }^{3}$ Laboratório de Biologia Celular e Tecidual, Centro de Biociências e Biotecnologia, Universidade Estadual do Norte \\ Fluminense Darcy Ribeiro.
}
* Corresponding author: 'Laboratório de Ciências Ambientais, Centro de Biociências e Biotecnologia, Universidade Estadual do Norte Fluminense Darcy Ribeiro, Campos dos Goytacazes, 28013-602, Rio de Janeiro, Brazil; Tel +55 222739 7138. e-mail: apvitoria@gmail.com

Received: 16 June 2010; Accepted: 02 November 2010

\begin{abstract}
The photosynthetic dynamics of the tropical pioneer species, Byrsonima sericea DC., were studied during the regeneration process of a native forest by evaluating ecophysiological (gas exchange, chlorophyll a fluorescence and photosynthetic pigment contents) and anatomical parameters of plants in sunny and shady environments. Ecophysiological evaluations were carried out monthly for one year, encompassing both a dry and a rainy season. Byrsonima sericea DC. presents anatomical plasticity that enables it to establish in environments with contrasting light regimes. In sunny conditions, it produced a thicker leaf (about $420 \mathrm{~mm}$ ) and flat adaxial epidermis, whilst in the shade, leaves had a thinner convex adaxial epidermis (about $395 \mathrm{~mm}$ ). No differences were found in the compositions of the pigments in the different environments, however, during the dry season, the plants presented a significantly higher concentration of photosynthetic pigments. In the sun, plants showed decreases in Fv/F0 ratio (in the rainy season) and NPQ (in the dry season), but no difference was observed between plants that were in the sun or in the shade. A significantly higher net photosynthetic rate was found only in the rainy season in the plants in the sun, compared to shaded plants ( $9.9 \pm 0.8$ and $7.4 \pm 0.3 \mu \mathrm{mol} \mathrm{m}^{-2} \mathrm{~s}^{-1}$, respectively). Significant increase in transpiration was observed in plants in the shade during the dry season, but no alterations were observed in the water use efficiency. Ecophysiological data suggest that mainly plants overexposed to the sun underwent water limitations during the dry season and that, in the rainy season, these plants increased their net photosynthetic rate, possibly due to the greater drainage force resulting from increased growth during this period. Data suggest that anatomic alterations, namely the convex adaxial epidermis, could aid in the supply of light to shaded plants during both seasons, precluding changes in the pigments, such as the increase in chlorophyll $b$ usually observed in shaded plants, but not detected in the present study. Another consequence of the greater quantity of light captured by these shade plants is that during the dry season their net photosynthetic rate was not different from that of plants in a sunny environment. However, when water was not a limiting factor, a better photosynthetic performance was observed in this pioneer specie in open spaces.
\end{abstract}

Key words: Atlantic forest species; photosynthetic adaptation; leaf anatomy; sun overexposure; shaded plants. 


\section{RESUMO}

A dinâmica fotossintética da espécie pioneira tropical Byrsonima sericea DC. foi estudada durante o processo de regeneração de uma mata nativa por avaliações ecofisiológicas (trocas gasosas, fluorescência da clorofila a e conteúdo de pigmentos fotossintéticos) e parâmetros anatômicos das plantas em ambientes ensolarados e sombreados. As avaliações ecofisiológicas foram feitas mensalmente por um ano e os dados foram agrupados em estação seca e chuvosa. Byrsonima sericea DC. apresentou plasticidade anatômica que a capacita a se estabelecer em ambientes com contrastantes condições luminosas. Nas condições ensolaradas, ela produz lâmina foliar mais espessa (cerca de $420 \mu \mathrm{m}$ ) e epiderme adaxial plana, enquanto em ambientes sombreados, as folhas apresentaram a epiderme convexa e lâmina mais delgada (cerca de $393 \mu \mathrm{m}$ ). Não foram encontradas diferenças significativas na composição de pigmentos em função do ambiente, no entanto, durante a estação seca, as plantas apresentaram concentrações significativamente maiores de pigmentos fotossintéticos. As plantas de ambientes ensolarados mostraram diminuição na razão $\mathrm{Fv} /$ F0 (na estação chuvosa) e NPQ (na estação seca), mas não foram observadas diferenças entre as plantas de sol ou sombra numa mesma estação do ano. Taxas fotossintéticas significativamente maiores foram encontradas na estação chuvosa para as plantas de sol quando comparadas com as plantas de sombra $\left(9.9 \pm 0.8\right.$ e $7.4 \pm 0.3 \mu \mathrm{mol} \mathrm{m}^{-2} \mathrm{~s}^{-1}$, respectivamente). Aumento significativo na transpiração foi observado em plantas de sombra durante a estação seca, mas sem afetar a eficiência no uso da água. Dados ecofisiológicos sugerem que, principalmente as plantas mais expostas ao sol sofreram limitações hídricas durante a estação seca e que, na estação chuvosa, estas plantas aumentaram sua taxa fotossintética. Isso possivelmente foi devido a maior força de dreno resultante do maior crescimento neste período. Os dados sugerem que alterações anatômicas, especialmente a epiderme adaxial convexa, estariam auxiliando na captação de luz nas plantas sombreadas durante ambas as estações, prevenindo alterações nos pigmentos, como 0 aumento de clorofila $b$ geralmente observado em plantas de sombra, mas não detectado no presente estudo. Outra conseqüência da maior quantidade de luz capturada por estas plantas de sombra foi que, durante a estação seca sua taxa fotossintética não diferiu da das planas de ambientes ensolarados. No entanto, quando a água não foi um fator limitante, um melhor desempenho fotossintético foi observado nesta espécie pioneira, em ambientes abertos.

Palavras-chave: espécies de Mata Atlântica; adaptação fotossintética; anatomia foliar; exposição excessiva ao sol; plantas de sombra.

\section{INTRODUCTION}

The Brazilian remnants of the Atlantic Forest have been and continue to be subject to various anthropogenic pressures, mainly from forest fragmentation (Morellato and Haddad, 2000). This process exposes the plants to a high light intensity, sudden fluctuations in temperature and higher vapor pressure deficits (Camargo and Kapos, 1995). A higher light intensity directly influences community architecture (Souza et al., 2009) and floristic composition (Murcia, 1995), influencing the establishment of pioneer species. These species generally have higher photosynthetic rates with large accumulation of biomass and low susceptibility to photoinhibition, in comparison to climax species (Silvestrini et al., 2007).

Plants of all successional stages continually adapt to alterations in light. Photosynthetic induction occurs rapidly, in minutes (Rijkers et al., 2000), whilst photosynthetic adjustments can take days (Cai et al., 2005) and morphological alterations are observed after weeks or months (Ackerly, 1997). Within the plasticity possible for each successional state, plants adjust their pigments, photosynthesis, ultra-structure and anatomy in response to light (Oguchi et al., 2003; Rozendaal et al., 2006; Terashima et al., 2006; Sarijeva et al., 2007). As such, plants in the sun and in the shade differ in various aspects. The warming of plants in the sun, due to excessive light capture, may be balanced by transpiration via the reduction of the boundary layer resistance (Givnish, 1984) and increases in the dissipation of energy, in the form of heat (nonphotochemical quenching of fluorescence - NPQ) (Behera et al., 2003). Plants exposed to sun possess chloroplasts that are adapted to perform high rates of light conversion into chemical energy. Such plants possess a higher photosynthetic capacity in a given area, a greater concentration of chlorophyll, a higher chlorophyll (chl) $a / b$ ratio and less light-harvesting chl $a / b$ proteins (LHCII) than shade plants (Lichtenthaler and Burkart, 1999). Shaded plants invest in strategies for better capture and utilization of light, such as increases in specific leaf area (Sarijeva et al., 2007) and a reduction in respiration rate (Bjorkman, 1981).

Besides light, other abiotic factors such as seasonal variations in temperature and water may greatly influence photosynthetic performance and plant anatomy (Gratani et al., 2008; Herrera 
et al., 2009). Usually in the dry season there is a reduction in photosynthetic assimilation and transpiration as a consequence of reduced stomatal conductance (Prado et al., 2004). Many ecophysiological studies involving sun and shade plants have reported comparisons between plants of different successional stages (Souza et al., 2005; Silvestrini et al., 2007; Portes et al., 2008) or of the same species (Nobel, 1976; Dias et al., 2007; Li et al., 2009; Dai et al., 2009). Although studies relating several successional stages are extremely important for understanding the function of the species that integrate an ecosystem, studies involving only one successional group in different environmental conditions, after human impacts, may help to understand the effect of forest fragmentation on the adaptive responses of these plants.

In an abandoned old eucalyptus plantation with native forest regeneration, in União Biological Reserve (Brazil), the pioneer species, Byrsonima sericea DC. (Malpighiaceae), has established itself naturally. It presents perennefolia and heliophyte characteristics and is commonly found in forests located in altitude regions, both in dry and humid terrains. This species has an important ecologic function, since its fruits and flowers attract pollinators and dispersers, favoring the regeneration of other native species (Teixeira and Machado, 2000).

In this study, we investigated photosynthetic and anatomical characteristics of the pioneer species, $B$. sericea DC., over one year in two distinct areas of light availability (sun and shade) in the União Biological Reserve aiming to identify the adaptive strategies in response to different light conditions upon dry and rainy seasons.

\section{MATERIAL AND METHODS}

Study sites, species and environmental characterization: The study was carried out in an abandoned old eucalyptus plantation with natural native forest regeneration in the União Biological Reserve, Rio de Janeiro State, Brazil (22 27' 30" S, $42^{\circ} 02^{\prime} 14^{\prime \prime}$ W). Byrsonima sericea DC. (Malpighiaceae) is a pioneer and evergreen tree species. Ten adult individuals of $B$. sericea DC. with heights of between 3-4 $\mathrm{m}$ were marked and evaluated monthly in two forest gaps, denominated as sun and shade sites. The maximum distances between individuals were $30 \mathrm{~m}$ in the sunny site and $35 \mathrm{~m}$ in the shaded site.

Ecophysiological measurements were taken between August 2007 and August 2008, except during the months of January and July for gas exchange analysis. Measurements of chlorophyll a fluorescence and photosynthetic pigments were taken monthly during these 13 months. For quantification of pigment,
10 individuals were utilized, for gas exchange and chlorophyll a fluorescence measurements, 5 individuals were used from each site. The anatomical evaluations were performed on 3 leaves from 3 individuals in each environment, collected in January 2008.

The environmental data sets for 2007 and 2008 are presented in Figure 1 (macro-environmental data) and Table 1 (micro-environmental data). Due to the prevailing rainfall regime in the experimental area (Figure 1), the ecophysiological results were grouped into the rainy season (October 2007 to April 2008) and the dry season data (August and September 2007 and May to August, 2008). The data were measured in 20 points for five consecutive days at dry and rainy season between 11:00 and 13:30 h (Evaristo, 2008).

Table 1. Environmental conditions during the dry and rainy season of 2007 for sun and shade sites in União Biological Reserve, Brazil. The data were measured between 11:00 and 13:30 h. PPFD (photosynthetic photon flux density). Lowercase letters indicate statistical differences between sites in same season $(p<0.05)$. ANOVA one-way. Source: Evaristo (2008).

\begin{tabular}{ccccc}
\hline Microclimate variables & \multicolumn{4}{c}{ Season } \\
\cline { 2 - 5 } & \multicolumn{3}{c}{ Dry } & \multicolumn{2}{c}{ Rainy } \\
\cline { 2 - 5 } & sun & shade & sun & shade \\
\cline { 2 - 5 } Soil water (\%) & $12.32^{\mathrm{b}}$ & $14.37^{\mathrm{a}}$ & $17.41^{\mathrm{a}}$ & $17.51^{\mathrm{a}}$ \\
Air temperatures $\left({ }^{\circ} \mathrm{C}\right)$ & $37.46^{\mathrm{a}}$ & $29.47^{\mathrm{b}}$ & $39.76^{\mathrm{a}}$ & $35.91^{\mathrm{b}}$ \\
Relative humidity $(\%)$ & $40.25^{\mathrm{b}}$ & $47.9^{\mathrm{a}}$ & $41.1^{\mathrm{b}}$ & $53.35^{\mathrm{a}}$ \\
PPFD $\left(\mu \mathrm{mol} \mathrm{s}^{-1} \mathrm{~m}^{-2}\right)$ & $800.59^{\mathrm{a}}$ & $184.35^{\mathrm{b}}$ & $781.00^{\mathrm{a}}$ & $94.45^{\mathrm{b}}$ \\
\hline
\end{tabular}

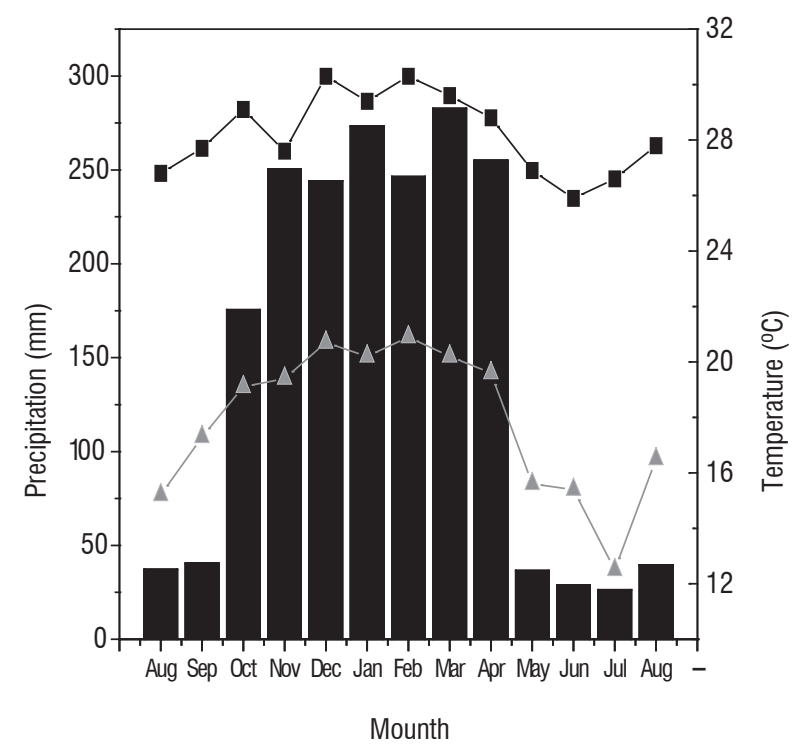

Figure 1. Macroclimate refers to meteorological data recorded between August 2007 to August 2008 with an automatic weather station in União Biological Reserve, Brazil. $\Delta$ Minimal temperature, - Maximal temperature. 
Gas exchange: Net photosynthetic rate $\left(P_{\mathrm{N}}\right)$, stomatal conductance $\left(g_{\mathrm{s}}\right)$ and transpiration $(E)$ were determined at between 7:30 and 9:30 $\mathrm{h}$ (period corresponding to the maximum $g_{s}$ ). The leaves were measured with a wearable infrared gas analyzer (Ciras 2, PPSystem, UK) with a clamp-on leaf cuvette that exposed $1.7 \mathrm{~cm}^{2}$ of leaf area. Saturated light (PPFD), temperature and humidity were $1300 \mu \mathrm{mol} \mathrm{m}^{-2} \mathrm{~s}^{-1}, 25 \pm 2{ }^{\circ} \mathrm{C}$ and $75 \%$, respectively. $\mathrm{CO}_{2}$ was maintained at a constant level of $370 \mu \mathrm{mol} \mathrm{mol}^{-1}$. Light was imposed using the Ciras 2 LED light source (PP-System). Water use efficiency (WUE) was calculated as the ratio $P_{N} / g_{\mathrm{s}}$ (Nobel, 1999). Each measurement was carried out on 4 newly matured leaves of the third pair per plant and was repeated on 5 plants for each site (n: 5).

Chlorophyll a fluorescence: These measurements were carried out at between 9:30 and 11:00 h using a pulse amplitude modulation fluorimeter (FMS2, Hansatech Instruments Ltd., Norfolk, UK). Four intact and healthy leaves from each plant (same as those used for gas exchange) were kept in the dark for $30 \mathrm{~min}$ and then exposed to the weak, modulated beam light (approximately $6 \mu \mathrm{mol} \mathrm{m} \mathrm{m}^{-2} \mathrm{~s}^{-1}$ at $660 \mathrm{~nm}$ ), followed by exposure (for $0.8 \mathrm{~s}$ ) to high intensity $\left(10000 \mu \mathrm{mol} \mathrm{m}^{-2} \mathrm{~s}^{-1}\right.$ ) actinic white light, as adapted by Genty et al. (1989). The minimum fluorescence (FO), the maximum fluorescence (Fm), NPQ (nonphotochemical quenching of fluorescence), qNP (coefficient of nonphotochemical quenching of fluorescence) and $\mathrm{qP}$ (coefficient of photochemical quenching of fluorescence) were measured by fluorimeter FMS2. The variable fluorescence ( $F v=F m$ - F0), maximum quantum yield of photosystem (PS) II (Fv/Fm) and variable chlorophyll fluorescence ratio (Fv/FO) were calculated according to Van Kooten and Snel (1990) and Pereira et al. (2000). Each measurement was carried out on four newly maturated leaves per plant and was repeated on five plants for each site $(n=5)$.

Photosynthetic pigments: Three discs were taken from 10 plants (matured leaves of the third pair) from the sunny and shady sites $(n=10)$. The 3 discs were sliced and placed in plastic tubes in the dark with a lid containing $5 \mathrm{~mL}$ dimethylsulfoxide reagent (DMSO) as organic solvent. After 5 days, the extract was analyzed in a spectrophotometer at wavelengths of 480 , 649 and $665 \mathrm{~nm}$. The photosynthetic pigments were quantified according to Wellburn (1994). All the laboratory procedures were carried out in a low light environment. The values are

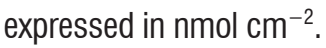

Anatomical measurements: Leaf fragments were fixed in the field with a solution of $2.5 \%$ glutaraldehyde and $4 \%$ paraformaldehyde in $0.05 \mathrm{M}$ cacodylate buffer at $\mathrm{pH} 7.2$ and transported to the laboratory. The samples were rinsed 3 times with buffer and post-fixed for $2 \mathrm{~h}$ at room temperature with $1 \%$ osmium tetroxide in $0.05 \mathrm{M}$ cacodylate buffer at $\mathrm{pH} 7.2$. The post-fixed samples were dehydrated in a graded series of acetone solutions. Subsequently, the material was infiltrated and embedded in Epoxy resin (Polybed). Microtome sections $(1.0 \mathrm{~mm})$ were cut and stained with toluidine blue $(0.05 \%$ aqueous solution). The slides were sealed with Entellan ${ }^{\circledR}$ (Merck) and examined with an Axioplan ZEISS microscope. Measurements were taken following leaf anatomy parameters in the epidermis, mesophyll and vascular bundle. Anatomical description and measurements were performed with the aid of the image analysis software, analySIS ${ }^{\circledR}$, in the Axioplan Zeiss microscope. Three individuals were evaluated in each site (n: 3 ) and 1 leaf was sampled from each individual. For each leave, 2 fields were examined and 3 measurements of each parameter were made. The results are presented as arithmetic mean and standard error.

Statistical analysis: The results of gas exchange, chlorophyll a fluorescence and photosynthetic pigments were analyzed by two-way analysis of variance (ANOVA), the anatomical measurement were analyzed by one-way analysis of variance (ANOVA). The means were compared using Tukey's test $(p<0.05)$.

\section{RESULTS}

ANOVA two-way analysis for gas exchange data showed interactions between season and sites for the variables net photosynthetic rate and transpiration. Plants in the sun decreased their transpiration during the dry season and increased their net photosynthetic rate during the rainy season (Figure 2). Although no statistical differences were found between the sites, in the dry season the shaded plants tended to demonstrate a higher gas exchange than plants in the sun. In contrast, the opposite was observed in the rainy season, when net photosynthetic rate stomatal conductance and transpiration were higher in plants in the sun. Others tendencies verified were the higher water use efficiency (WUE) in the dry season and the increase in WUE in plants in the sun, for both seasons. 

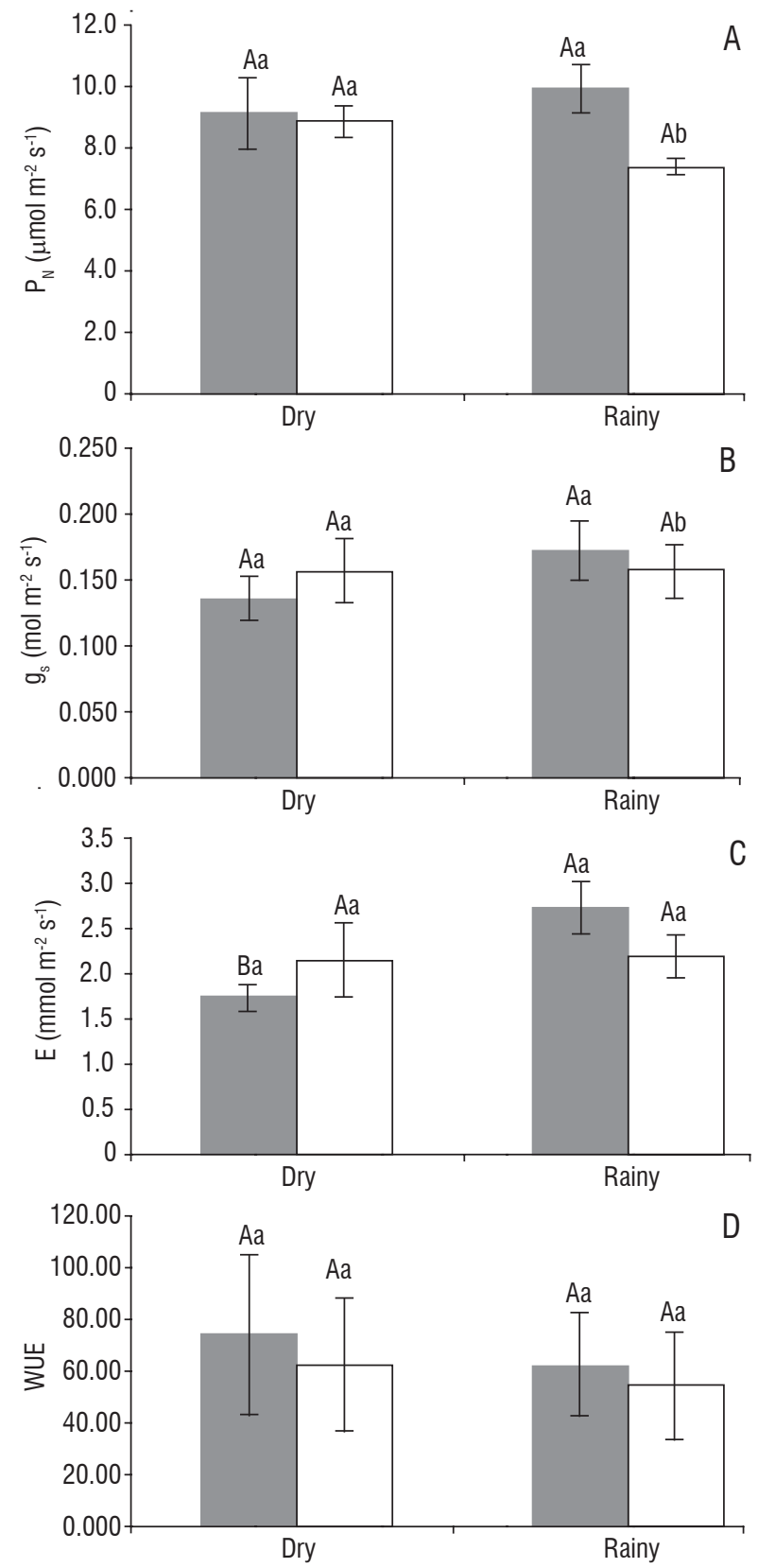

Figure 2. A- Net photosynthetic rate $\left(P_{\mathrm{N}}\right)$, B- stomatal conductance $\left(g_{\mathrm{s}}\right)$, Ctranspiration $(E)$ and $D$ - water use efficiency (WUE) for sun $\square$ and shade Byrsonima sericea DC. plants in the dry and rainy seasons of 2007 and 2008. Different uppercase letters indicate statistical differences between season, lowercase letters indicate statistical difference between sites $(p<0.05)$. ANOVA two-way. The data are means $\pm \mathrm{SE}$.

$\mathrm{Fv} / \mathrm{Fm}$, qP and qNP were not affected by site or season (Table 2). However, in the dry season, plants in the sun demonstrated higher Fv/F0 and lower NPQ $(p<0.05)$ than in the rainy season (Table 2). For these parameters, statistical analyses showed interactions between seasons and sites. The concentrations of chl $a, b$, total chl and carotenoids were higher in the dry season in both sites $(p<0.05)$ (Table 2). However, no statistical differences were found for the $\mathrm{chl} a / b$ ratios and total chl/ carotenoids. The photosynthetic pigments did not present alterations due to light conditions and no interactions between season and sites were found.

Table 2. Chlorophyll a fluorescence parameters and photosynthetic pigments in sun and shade plants of Byrsonima sericea DC. in dry and rainy seasons. $\mathrm{Fv} / \mathrm{Fm}$, potential quantum efficiency; Fv/F0, variable potential quantum efficiency; NPQ, nonphotochemical quenching of fluorescence; qNP, coefficient of nonphotochemical quenching of fluorescence; qP, coefficient of photochemical quenching of fluorescence; Chl, chlorophyll; Caro, carotenoids. Uppercase letters indicate statistical differences between seasons; lowercase letters indicate statistical difference between sites $(p<0.05)$. ANOVA twoway. The data are mean \pm SE.

\begin{tabular}{|c|c|c|c|}
\hline & & Dry & Rainy \\
\hline \multirow[t]{2}{*}{$\mathrm{F}_{\mathrm{v}} / \mathrm{F}_{\mathrm{m}}$} & sun & $0.83 \pm 0.01^{\mathrm{Aa}}$ & $0.81 \pm 0.02^{\mathrm{Aa}}$ \\
\hline & shade & $0.83 \pm 0.01 \mathrm{Aa}$ & $0.81 \pm 0.03^{\mathrm{Aa}}$ \\
\hline \multirow[t]{2}{*}{$F_{v} / F_{0}$} & sun & $4.87 \pm 0.36^{\mathrm{Aa}}$ & $4.36 \pm 0.58^{\mathrm{Ba}}$ \\
\hline & shade & $4.71 \pm 0.26^{\mathrm{Aa}}$ & $4.70 \pm 0.78^{\mathrm{Aa}}$ \\
\hline \multirow[t]{2}{*}{$q P$} & sun & $0.82 \pm 0.05^{\mathrm{Aa}}$ & $0.84 \pm 0.04{ }^{\mathrm{Aa}}$ \\
\hline & shade & $0.80 \pm 0.05^{\mathrm{Aa}}$ & $0.82 \pm 0.06^{\mathrm{Aa}}$ \\
\hline \multirow[t]{2}{*}{ qNP } & sun & $0.44 \pm 0.03^{\mathrm{Aa}}$ & $0.47 \pm 0.07^{\mathrm{Aa}}$ \\
\hline & shade & $0.49 \pm 0.05^{\mathrm{Aa}}$ & $0.49 \pm 0.12^{\mathrm{Aa}}$ \\
\hline \multirow[t]{2}{*}{$N P Q$} & sun & $0.56 \pm 0.03^{\mathrm{Ba}}$ & $0.64 \pm 0.16^{\mathrm{Aa}}$ \\
\hline & shade & $0.69 \pm 0.12^{\mathrm{Aa}}$ & $0.72 \pm 0.28^{\mathrm{Aa}}$ \\
\hline \multirow[t]{2}{*}{ Chl a $\left(\mathrm{nmol} \mathrm{cm}^{-2}\right)$} & sun & $32.39 \pm 4.70^{\mathrm{Aa}}$ & $22.68 \pm 2.72^{\mathrm{Ba}}$ \\
\hline & shade & $30.27 \pm 5.18 \mathrm{Aa}$ & $23.41 \pm 3.31^{\mathrm{Ba}}$ \\
\hline \multirow[t]{2}{*}{$\mathrm{Chl} b\left(\mathrm{nmol} \mathrm{cm}{ }^{-2}\right)$} & sun & $11.78 \pm 1.86^{\mathrm{Aa}}$ & $7.61 \pm 1.05^{\mathrm{Ba}}$ \\
\hline & shade & $11.74 \pm 2.28^{\mathrm{Aa}}$ & $8.29 \pm 1.25^{\mathrm{Ba}}$ \\
\hline \multirow[t]{2}{*}{$\mathrm{Chl} a / b$} & sun & $3.00 \pm 0.41^{\mathrm{Aa}}$ & $3.10 \pm 0.48 \mathrm{Aa}$ \\
\hline & shade & $2.90 \pm 0.59 \mathrm{Aa}$ & $2.90 \pm 0.46^{\mathrm{Aa}}$ \\
\hline \multirow[t]{2}{*}{ Caro $\left(\mathrm{nmol} \mathrm{cm}{ }^{-2}\right)$} & sun & $12.07 \pm 1.17^{\mathrm{Aa}}$ & $8.24 \pm 0.66^{\mathrm{Ba}}$ \\
\hline & shade & $10.71 \pm 1.22 \mathrm{Aa}$ & $7.42 \pm 0.68$ ва \\
\hline \multirow[t]{2}{*}{ Total Chl $\left(\mathrm{nmol} \mathrm{cm}{ }^{-2}\right)$} & sun & $45.04 \pm 6.48 \mathrm{Aa}$ & $30.82 \pm 4.11^{\mathrm{Ba}}$ \\
\hline & shade & $43.48 \pm 7.46^{\mathrm{Aa}}$ & $32.54 \pm 4.54^{\mathrm{Ba}}$ \\
\hline \multirow[t]{2}{*}{ Total Chl/Caro } & sun & $3.50 \pm 0.60^{\mathrm{Aa}}$ & $3.70 \pm 0.60^{\mathrm{Aa}}$ \\
\hline & shade & $3.80 \pm 0.90^{\mathrm{Aa}}$ & $4.20 \pm 0.70^{\mathrm{Aa}}$ \\
\hline
\end{tabular}


Anatomical analyses showed that plants in the sun had thicker leaf blades and mesophyll $(p<0.05)$ than shaded plants (Figure 3 $A$ and $B$ and Table 3). However, shaded plants had thicker adaxial epidermal cells than those of plants in the sun $(p<0.05)$, with no significant difference in the thickness of the abaxial epidermis (Figure $3 \mathrm{C}$ and $\mathrm{D}$ and Table 3 ). External outer cell walls of the adaxial epidermis cells of the shaded plants were more convex than the epidermis of sun plants (Figure $3 \mathrm{C}$ and $\mathrm{D}$, arrows).

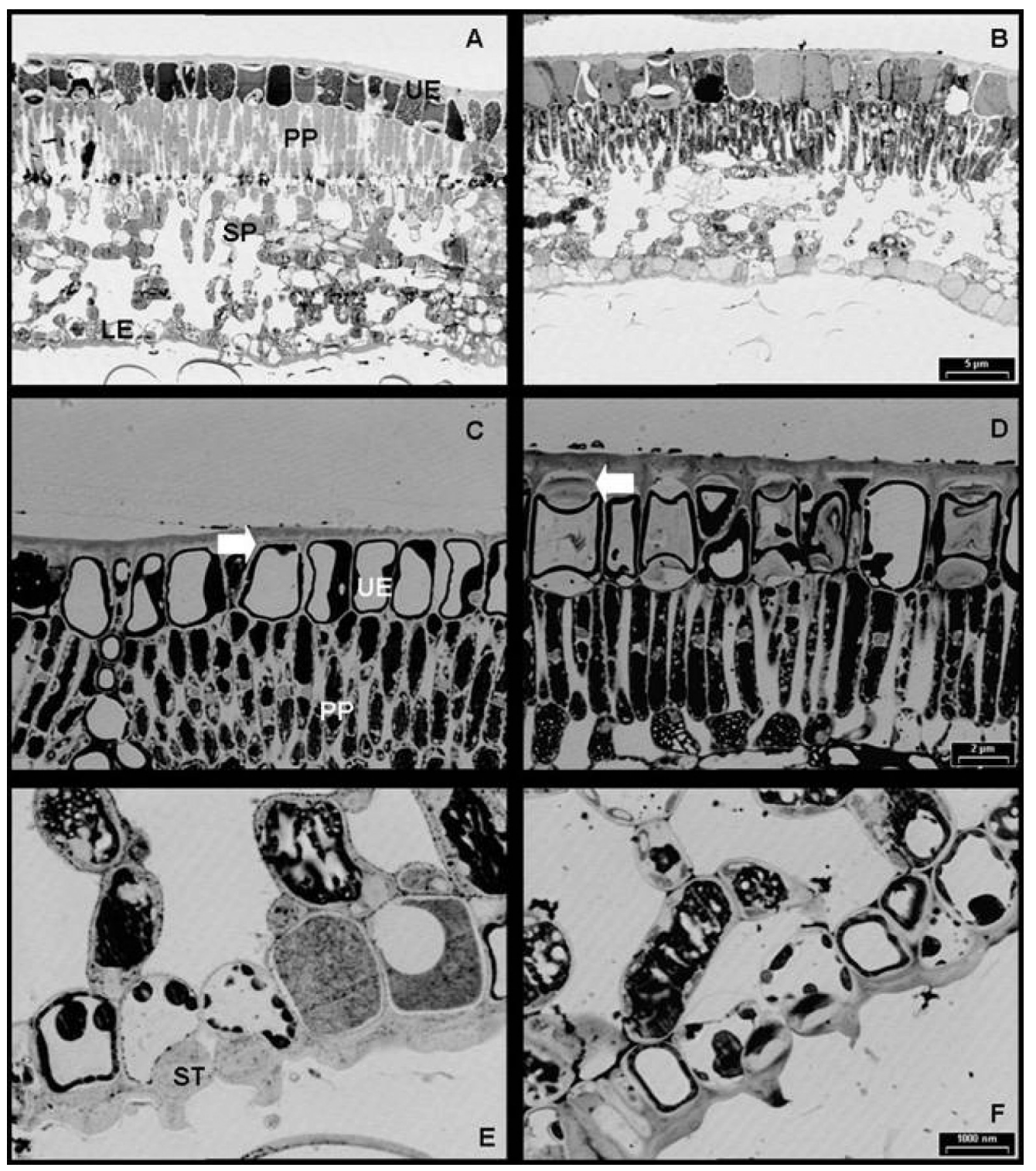

Figure 3. Transverse sections of Byrsonima sericea leaves from sunny ( $A, C$ and $E$ ) and shaded (B, D and F) sites. A and B: leaf blade, same scale; $C$ and D: adaxial epidermis, same scale; E and F: stomata in the abaxial epidermis, same scale. Arrows indicate the convexity of the epidermis. Abbreviations: PP, Palisade Parenchyma; SP, Spongy Parenchyma; EU, Upper Epidermis; LE, Lower Epidermis; ST, Stomata. 
Table 3. Leave anatomical measures $(\mu \mathrm{m})$ of Byrsonima sericea DC. plants in sun and shade sites. Different letters indicate statistical difference between sites $(p<0.05)$. ANOVA one-way. The data are mean \pm SE.

\begin{tabular}{ccc}
\hline Leaf characteristics & Sun & Shade \\
\hline Leaf thickness & $421.2 \pm 20.6^{\mathrm{a}}$ & $396.4 \pm 11.7^{\mathrm{b}}$ \\
Palisade thickness & $157.7 \pm 12.0^{\mathrm{a}}$ & $139.2 \pm 7.1^{\mathrm{b}}$ \\
Spongy parenchima thickness & $169.8 \pm 16.5^{\mathrm{a}}$ & $143.9 \pm 7.1^{\mathrm{b}}$ \\
Upper epidermis thickness & $70.0 \pm 2.9^{\mathrm{b}}$ & $78.2 \pm 2.6^{\mathrm{a}}$ \\
Lower epidermis thickness & $30.0 \pm 2.1^{\mathrm{a}}$ & $32.0 \pm 1.4^{\mathrm{a}}$ \\
Mesophyll thickness & $327.5 \pm 19.8^{\mathrm{a}}$ & $283.1 \pm 8.8^{\mathrm{b}}$ \\
\hline
\end{tabular}

\section{DISCUSSION}

The results reveal ecophysiological and anatomical adaptations in $B$. sericea DC., depending on the light exposure (sunny or shady) and season (dry or rainy). In the rainy season, plants in the sun have a higher net photosynthetic rate than shaded plants, possible due to a higher sink demand (growth) and leaf acclimation. Greater growth rates and carbon absorption were observed during the rainy season, characterized by higher temperatures, as previously reported in the literature, including studies from Brazil (Pozer and Nogueira, 2004; Silva et al., 2004). In coffee plants, Silva et al. (2004) found an increased growth rate of plants, higher net carbon absorption during the months of October to March (rainy season) and a reduction in during the months of April to September (dry season).

The fact that sun plants, such as $B$. sericea DC., are more photosynthetically active corroborates observations by other authors, who have shown that pioneer species have higher photosynthetic rates, especially in sunny environments (Nogueira et al., 2004; Silvestrini et al., 2007). Moreover, during the rainy season, water conditions favor photosynthetic performance (Prado et al., 2004). In contrast, in the dry season, there was a strong tendency for shaded plants to present a higher gas exchange than leaves in the sun. Based on the values of transpiration and stomatal conductance, plants in the sun were under severer water stress, compared to shaded plants, whereas in the rainy season, stomatal conductance was equal in the different sites. In sun plants, transpiration was lower in the dry season than in the rainy season (Figure 2). Usually, in the dry season, there is greater control of the stomatal opening, allowing a more effective maintenance of the leaf water potential (Brodribb and Holbrook, 2003; Prado et al., 2004). Miranda et al. (2011) observed during the dry season in Chapada Diamantina, Brazil, lower variation of leaf water potential in five tropical arboreal species from different phenological classes (reflecting transpiration restrictions) and suggested that this may occur via different mechanisms, like fall leaves, stomatal closing and other endogenous characteristics depending on the species.

According to Nogueira et al. (2004), pioneer species growing in open environments present higher WUE than late succession species, probably due to their higher photosynthetic rate capacity. In plants in the sun, during the dry season, the lowest stomatal conductance and transpiration was associated with lower values of net photosynthetic rate, resulting in the higher value of WUE observed. In the rainy season, the differences in WUE between sun and shade plants decreased, suggesting that the presence of water was an important stress factor in plants in the sun during the dry season, with regard to gas exchange. Ecophysiological responses may have an important impact on the performance of species occupying contrasting environments. Open habitats show relatively high variability in the environmental conditions (irradiance, water availability, and soil and air temperatures). Shaded areas protect plants from moisture stress by providing lower VPD (vapor pressure difference) and the physical environment tends to be relatively less variable. In these conditions, net photosynthetic rate and growth rates of pioneer trees are lower compared to sunny sites as the behavior of pioneer species is typically opportunistic, using the resources (water and light) in accordance with their availability in the environment (Zangler and Bazzaz, 1983; Nogueira et al., 2004). As such, when water is available, the higher light intensity of a sunny environment can induce higher photosynthetic rates in pioneer species.

Based on the results of chl a fluorescence (Table 2), over time, data suggest that the dry season or exposure of leaves to light has no great impact on the efficiency of the PS II, because no difference was observed in the Fv/Fm ratio between the plants in the sun and shade or between the dry and rainy season. The $\mathrm{Fv} / \mathrm{Fm}$ values are within the range $(0.75$ to 0.85$)$ suggested by Bolhar-Nordenkampf et al. (1989) to be indicative of unstressed plants. In agreement with these data, Morais et al. (2007) also suggested that the dry season of the Amazon region is not sufficient to cause negative alterations in the $\mathrm{Fv} / \mathrm{Fm}$ ratios of the species evaluated, whose values were also close to 0.8 . 
Statistical analysis indicated the Fv/FO ratio as the more effective in discriminating the efficiency of the photosynthetic apparatus. Others authors have suggested the use of the Fv/FO ratio, rather than the $\mathrm{Fv} / \mathrm{Fm}$ ratio, for better discrimination of small differences in the PS II quantum yield (Paiva et al., 2009; Pereira et al., 2000; Sarajeva et al., 2007; Oliveira et al., 2009; Vitória et al., 2010). In contrast, Roháček (2002) reported that the Fv/ F0 ratio in healthy plants can vary between 4 and 6 , suggesting that despite it decreases in sun plants during the rainy season, this could not be well correlated with a stressed condition, as the performance of PS II quantum yield proved to be

In the dry season, there were systematically higher concentrations of all photosynthetic pigments analyzed (Table 2). This increased pigment accumulation in leaf cells may have occurred due to the lower relative water content in the leaves, caused by lower water availability in this season. Although the relative water content and leaf area were not analyzed in this study, the data of soil water percentage (Table 1) supported this hypothesis. No significant differences were found in the composition of photosynthetic pigments between plants under sun or shade (Table 2) in contrast with the common notion that higher chlorophyll levels are expressed in shaded conditions (Almeida et al., 2005; Dias et al., 2007; Dai et al., 2009).

Our data showed a tendency towards higher carotenoid levels and a lower total chl/carotenoid ratio in sun plants for both seasons. Such data is corroborated by Sarijeva et al. (2007), studying Ginko biloba L. and Fagus sylvatica L, in contrasting light conditions. Higher carotenoid accumulation is a common physiological strategy to the plant protection against photoinhibition. These pigments dissipate efficiently the excess of light energy in a non-destructive way, avoiding the PS II damage (Demmig-Adams et al., 1989).

Leaves of shaded plants were shown to be thinner than those of plants in the sun (Figure $3 \mathrm{~A}$ and $\mathrm{B}$ and Table 3), but developed a thicker adaxial epidermis (Figure $3 \mathrm{C}$ and $\mathrm{D}$ and Table 3). This change in the adaxial epidermis seems to be correlated with the higher convexity of this cell layer, also observed in shaded leaves (Figure $3 \mathrm{C}$ and D, arrows). Such variations in leaves can be seen as an anatomical strategy to concentrate luminous energy in the mesophyll cells in plants grown in an environment with low light intensity, in order to increase photosynthetic assimilation (Paiva et al. 2003). Pandey and Kushwaha (2005), evaluating the leaf anatomy of Valeriana jatamansi in contrasting light conditions, observed that leaves in the sun developed anatomical changes in the leaf mesophyll and in the adaxial epidermis, also expressing a thicker palisade parenchyma compared to shaded leaves.

Leaves of shaded plants are usually described as thinner, but with cells containing larger chloroplasts richer in chlorophyll than that of leaves of sun plants (Boardman, 1977; Dias et al., 2007; Sarajiva et al., 2007; Daí et al., 2009). Shaded plants are also expected to contain a higher proportion of $\mathrm{chl} b$ relative to chl a (Boardman, 1977). However, shaded plants of $B$. sericea DC. did not express this kind of chl adaptation, probably due to an adequate light supply provided by the higher convexity of their adaxial epidermis. Indeed, alterations in the anatomy and ultrastructure of the plants as a strategy to maintain physiological processes have been reported. Lage-Pinto et al. (2008) suggest that the grana disposition is substituted by lamellas, which are rich in PS I and poor in PS II, in water hyacinths exposed to urban pollution, in an adaptive attempt to maintain the flow of electrons, since the PS II is most sensitive to stress damage. According to these authors, this was an effective strategy to maintain the maximum quantum yield (Fv/Fm).

This study revealed the anatomic plasticity of $B$. sericea DC, when developed under sun or shade. However, the species' photosynthetic efficiency was not always higher in sunny environment as would be expected for a pioneer species (Nogueira et al., 2004). Our data showed that, during the dry season, shaded plants present advantages, possibly related to maintenance of micro-conditions (soil moisture and lower VPD) and anatomical adaptations, which may augment the light supply, in turn, maintaining a satisfactory gas exchange in this site.

In our experiment, since gas exchange measurements were made under constant PPFD and temperature, the differences in net photosynthetic rate reflected the intrinsic photosynthetic capacity of $B$. sericea DC. in each evaluated site and season. These data may explain why this pioneer species has been found in various stages of development even in shaded sites of this regenerating Atlantic forest environment, rather than prevailing in the sites overexposed to the sun, as occurs with the majority of pioneer species. The development of this pioneer species in locations shaded by abandoned eucalyptus plantations also provides further positive ecological consequences, including the availability of floral and fruit resources for the fauna, favoring processes of pollenization and dispersion of seeds of other species native of the Atlantic forest, thus, intensifying the regeneration of the native forest. 
Acknowledgments: The authors wish to thank Elmo Siqueira Carvalho for the aid in the field analysis.

\section{REFERENCES}

Ackerly D (1997) Allocation, leaf display, and growth in fluctuating light environments. In: F.A. Bazzaz \& J. Grace (Eds.), Plant Resource Allocation. Academic Press, San Diego, CA, USA.

Almeida SMZ, Soares AM, Castro EM, Vieira CV, Gajego EB (2005) Morphologic alterations and biomass allocation in young plants of forestry species under different conditions of shading. Ciência Rural. 35 (1): 62-68.

Behera RK, Choudhury NK (2003) High irradiance-induced changes in carotenoid composition and increase in non-photochemical quenching of Chl a fluorescence in primary wheat leaves. J. Plant Physiol. 160: 1141-1146.

Björkman 0 (1981) Responses to different quantum flux densities. In: O.L. Lange, P.S. Nobel, C.B. Osmond \& H. Ziegler (Eds.), Physiological Plant Ecology I. Responses to the Physical Environment, Springer, Heidelberg, New York. p. 57-107.

Boardman N K (1977) Comparative photosynthesis of sun and shade plants. Ann. Rev. Plant Physiol. 28: 355-77.

Bolhar-Nordenkampf HR, Long SP, Baker NR, Oquist G, Schreiber U, Lechner EG (1989) Chlorophyll fluorescence as a probe of the photosynthetic competence of leaves in the field: a review of current instrumentation. Funct. Ecol. 3(4): 497-514.

Brodribb TJ, Holbrook NM (2003) Stomatal closure during leaf dehydration, correlation with otherleaf physiological traits. Plant Physiol. 132: 2166-2173.

Cai ZQ, Rijkers T, Bongers F (2005) Photosynthetic acclimation to light changes in tropical monsoon forest woody species differing in adult stature. Tree Physiol. 25: $1023-1031$

Camargo JLC, Kapos V (1995) Complex edge effects on soil moisture and microclimate in Central Amazonian forest. J. Trop. Ecol. 11: 205-221.

Dai Y, Shen Z, Liu Y, Wang L, Hannaway D, Lu H (2009) Effects of shade treatments on the photosynthetic capacity, chlorophyll fluorescence, and chlorophyll content of Tetrastigma hemsleyanum Diels et Gilg. Environ. Exp. Bot. 65: 177-182.

Demmig-Adams B, Winter K, Kruger A, Czygan FC (1989) Light response of $\mathrm{CO}_{2}$ assimilation, dissipation of excess excitation energy, and zeaxanthin content of sun and shade leaves. Plant Physiol. 90: 881-886.

Dias J, Pimenta JA, Medri ME, Boeger MRT, Freitas CT (2007) Physiological aspects of sun and shade leaves of Lithraea molleoides (Vell.) Engl. (Anacardiaceae). Braz. Arch. Biol. Technol. 50(1): 91-99.

Evaristo V (2008). Dinâmica da comunidade e das principais populaces arbustivo-arbóreas da mata Atlântica em plantios abandonados de eucalipto (Corymbia citriodora (Hook.) K.D. Hill \& L.A.S.Johnson). Universidade Estadual do Norte Fluminense Darcy Ribeiro. MSc Thesis. 141 p.

Genty B, Briantais J-M, Baker NR (1989) The relationship between the quantum yield of photosynthetic electron transport and quenching of chlorophyll fluorescence. Bioch. Biophys. Acta 990: 87-92.

Gratani L, Varone L, Catoni R (2008) Relationship between net photosynthesis and leaf respiration in Mediterranean evergreen species. Photosynthetica. 46(4): 567-573.

Givnish TJ (1984) Leaf and canopy adaptations in tropical forests. In: E. Medina, H.A. Mooney \& C. Vasquez-Yanes (Eds.), Physiological Ecology of Plants in the Wet Tropics. Dr. Junk. The Hague. p. 51-84.

Herrera A, Escala M, Rengifo E (2009) Leaf anatomy changes related to physiological adaptations to flooding in Amazonian tree species. Braz. J. Plant. Physiol. 21 (4): 301-308.

Lage-Pinto F, Oliveira JG, Cunha M, Souza CMM, Rezende CE, Azevedo RA, Vitória AP (2008) Chlorophyll a fluorescence and ultrastructural changes in chloroplast of water hyacinth as indicators of environmental stress. Environ. Exp. Bot. 64: 307-313.

LiX, Dai Y, Chen S (2009) Growth and physiological characteristics of Fritillaria cirrhosa in response to high irradiance and shade in age-related growth phases. Environ. Exp. Bot. 67: 77-83.

Lichtenthaler HK, Burkart S (1999) Photosynthesis and high light stress. Bulg. J. Plant Physiol. 25(3-4): 3-16.

Miranda LAP, Vitória AP, Funch LS (2011) Leaf phenology and water potential of five arboreal species in gallery and montane forests in the Chapada Diamantina, Bahia, Brazil. Environ. Exp. Bot. 70: 143-150.

Morellato LPC, Haddad CFB (2000) Introduction: The Brazilian Atlantic Forest. Biotropica. 32(4): 786-792.

Morais RR, Gonçalves JFC, Santos Junior UM, Dunisch 0, Santos ALW (2007) Chloroplastid pigment contents and chlorophyll a fluorescence in amazonian tropical three species. Árvore 31 (5): 959-966.

Murcia C (1995) Edge effects in fragmented forests: implications for conservation. Trends Ecol. Evol. 10(2): 58-62.

Nobel PS (1976) Photosynthetic rates of sun versus shade leaves of Hyptis emoryi Torr.Plant Physiol. 58: 218-223.

Nobel PS (1999) Physicochemical \& Environmental Plant Physiology. Academic Press, San Diego.

Nogueira A, Martinez CA, Ferreira LL, Prado CHBA (2004) Photosynthesis and water use efficiency in twenty tropical tree species of differing succession status in a Brazilian reforestation. Photosynthetica. 42(3): 351-356.

Oguchi R, Hikosaka K, Hirose T (2003) Does the photosynthetic light-acclimation need change in leaf anatomy? Plant Cell Environ. 26: 505-512.

Oliveira JG, Alves PLCA, Vitória AP (2009) Alterations in chlorophyll a fluorescence, pigment concentrations and lipid peroxidation to chilling temperature in coffee seedlings. Environ. Exp. Bot. 67: 71-76.

Paiva EAS, Isaías RMS, Vale FHA, Queiroz CGS (2003) The influence of light intensity on anatomical structure and pigment contents of Tradescantia pallida (Rose) Hunt. cv. purpurea Boom (Commelinaceae) leaves. Brazil. Arch. Biol. Technol. 46(4): 617-624.

Paiva LB, Oliveira JG, Azevedo RA, Ribeiro DR, Silva MG, Vitória AP (2009) Ecophysiological responses of water hyacinth exposed to $\mathrm{Cr}^{3+}$ and $\mathrm{Cr}^{6+}$. Environ. Exp. Bot 65: 403-409.

Pandey S, Kushwaha R (2005) Leaf anatomy and photosynthetic acclimation in Valeriana jatamansi L. grown under high and low irradiance. Photosynthetica. 43(1): 85-90.

Pereira WE, Siqueira DL, Martinez CA, Puiatti M (2000) Gas exchange and chlorophyll fluorescence in four citrus rootstocks under aluminium stress. J. Plant Physiol. 157: 513-520.

Portes MT, Alves TH, Souza GM (2008) Time-course of photosynthetic induction in four tropical woody species grown in contrasting irradiance habitats. Photosynthetica. 46(3): 431-440.

Pozer CG, Nogueira F (2004) Flooded native pastures of the northern region of the pantanal of mato grosso: biomass and primary productivity variations. Braz. J. Biol. 64(4): 859-866.

Prado CHBA, Wenhui Z, Rojas MHC, Souza GM (2004) Seasonal leaf gas exchange and water potential in a woody cerrado species community. Brazil. J. Plant Physiol. 16(1): 7-16.

Rijkers T, de Vries PJ, Pons TL, Bongers F (2000) Photosynthetic induction in saplings of three shade-tolerant tree species: comparing understory and gap habitats in a French Guiana rain forest. Oecologia. 125: 331-340.

Roháček K (2002) Chorophyll fluorescence parameters: the definitions, photosynthetic meaning and mutual relationships. Photosynthetica 40(1): 13-29.

Rozendaal DMA, Hurtado VH, Poorter L (2006) Plasticity in leaf traits of 38 tropical tree species in response to light; relationships with light demand and adult stature. Func. Ecol. 20: 207-216. 
Sarijeva G, Knapp M, Lichtenthaler HK (2007) Differences in photosynthetic activity, chlorophyll and carotenoid levels, and in cholorophyll fluorescence parameters in green sun and shade leaves of Ginkgo and Fagus. J. Plant Physiol. 164: 950-955.

Silva EA, DaMatta FM, Ducatti C, Regazzic AJ, Barros RS (2004) Seasonal changes in vegetative growth and photosynthesis of Arabica coffee trees. Field Crops Res. 89: 349-357.

Silvestrini M, Válio IFM, Mattos EA (2007) Photosynthesis and carbon gain under contrasting light levels in seedlings of a pioneer and a climax tree from a Brazilian Semideciduous Tropical Forest. Rev. Bras. Bot. 30: 463-474.

Souza JP, Prado CHBA, Damascos MA, Albino ALS (2009) Influence of shoot inclination on irradiance and morphophysiological leaf traits along shoots in cerrado trees with distinct leaf deciduousness. Braz. J. Plant Physiol. 21(4): 281-289.

Souza GM, Ribeiro RV, Oliveira RF, Machado EC (2005) Network connectance and autonomy analyses of the photosynthetic apparatus in tropical tree species from different successional groups under contrasting irradiance conditions. Revista Brasileira de Botânica. 28(1): 47-59.
Terashima I, Hanba YT, Tazoe Y, Vyas P, Yano S (2006) Irradiance and phenotype: comparative eco-development of sun and shade leaves in relation to photosynthetic $\mathrm{CO}_{2}$ diffusion. J. Exp. Bot. 57(2): 343-354.

Teixeira LAG, Machado IC (2000) Pollination and reproductive system of Byrsonima sericea DC (Malpighiaceae). Acta Bot. Bras. 14(3): 347-357.

Van Kooten 0, Snel JFH (1990) The use of chlorophyll fluorescence nomenclature in plant stress physiology. Photos. Res. 25: 147-150.

Vitória AP, Lage-Pinto F, Campaneli LB, Almeida MG, Souza MCM, Rezende CE, Azevedo RA, Oliveira JG (2010) Ecophysiological adaptation and metal accumulation in water hyacinth from two tropical rivers. Braz. J. Plant Physiol. (22) 1: 49-59.

Wellburn AR (1994) The spectral determination of chlorophylls a and b, as well as total carotenoids, using various solvents with spectrophotometers of different resolution. J. Plant Physiol. 144(3): 307-313.

Zangler G, Bazzaz FA (1983) Responses of an early and a late successional species of Polygonum to variation in resource availability. Oecologia. 56: 397-408. 